\title{
Climatic fluctuations inferred for the Middle and Late Pleniglacial (MIS 2) based on high-resolution $(\sim$ ca. 20 y) preliminary environmental magnetic investigation of the loess section of the Madaras brickyard (Hungary)
}

\author{
Pál Sümegi \\ Department of Geology and Paleontology, University of Szeged, Szeged \\ Institute of Archeology, Hungarian Academy of Science, Budapest \\ Sándor Gulyás*, Bálint Csökmei, Dávid Molnár \\ Department of Geology and Paleontology, University of Szeged, Szeged \\ Ulrich Hambach \\ University of Bayreuth Chair of Geomorphology, Bayreuth \\ Thomas Stevens \\ Department of Geography, Royal Holloway University of London, London \\ Slobodan B. Markovic \\ Department of Geography, Hotel Management and Tourism, University of Novi Sad, Novi Sad \\ Peter C. Almond \\ Department of Soil and Physical Sciences, Lincoln University, Christchurch
}

\footnotetext{
The Madaras brickyard section found at the northernmost fringe of the Backa loess plateau is one of the thickest and best-developed last glacial loess sequences of Central Europe. In the present work high-resolution magnetic susceptibility measurements $($ at $2 \mathrm{~cm}$ ) were implemented on samples from the $10 \mathrm{~m}$-section corresponding to a period between 29 and $11 \mathrm{KY}$ cal b2K. One aim was to compare the findings with the ice core records of northern Greenland in order to establish a high-resolution paleoclimatic record for the last climatic cycle and with findings documented in other biotic and abiotic proxies so far. Our results revealed a strong variability of loess/paleosol formation during MIS 2. Millennial time-scale climatic events that characterize the North Atlantic during the last climatic cycle have been identified. From 29 ka up to the start of the LGM, the recorded MS values show a weak, negative correlation with the temperature proxy, and a weak positive correlation with the dust concentration of Greenland. A strong correlation was observed with the local paleotemperatures. Local climatic factors must have had a more prominent effect here on loess/paleosol development than the climate shifts over Greenland. During the LGM the same pattern is seen with a stronger

Addresses: P. Sümegi, S. Gulyás, B. Csökmei, D. Molnár: H-6722 Szeged Egyetem u. 2-6, Hungary U. Hambach: D-95440 Bayreuth, Universitätsstraße 30, Germany T. Stevens: Egham, Surrey TW20 0EX, UK S. B. Markovic: 21000 Novi Sad, Trig Dositeja Obradovića 3, Serbia P. C. Almond: PO Box 85084, Lincoln 7647 Canterbury, New Zealand * corresponding author's e-mail: gulyas-sandor@t-online.hu Received: October 25, 2012; accepted: February 6, 2013
} 
correlation with the dust concentrations and a weaker correlation with the local temperature. Local climatic factors, plus dust accumulation, must have had a prominent influence on loess/paleosol development here. From the terminal part of the LGM a strong positive correlation of the MS values with the temperature proxy for Greenland accompanied by a strong negative correlation with the dust concentration values is observed. Correlation with local paleotemperatures is positive and moderate, strong. Here climate shifts over Greenland, as well as local endowments equally had an important role on the development of the MS signal.

Key words: environmental magnetism, susceptibility, bidecadal variations, paleoclimate, late Quaternary, SE Hungary

\section{Introduction}

Loess sequences are among the best archives for terrestrial paleoenvironmental reconstructions, draping approximately 10\% of the planet's surface (Pécsi 1990). However, the presence of potential erosional and sedimentation hiatuses (Sümegi et al. 2011) calls for a strong chronological control, also including biostratigraphic data. Despite these potential pitfalls, which may introduce bias in the record, the geologic and biological information locked into these sequences is crucial in understanding the evolution of the Quaternary landscape (Sümegi 2001).

In order to correlate paleoenvironmental changes recorded in the loess sections with other coeval terrestrial and marine archives, as well as ice core sequences, a new method based on the investigation of environmental magnetism, originally used in the reconstruction of sedimentation rates in catchment basins, was devised in the 1970s (Oldfield et al. 1978). Environmental magnetism in loessic sediments is based on the enhancement of magnetic minerals, primarily iron oxides and hydroxides, through either pedogenesis (Babanin et al. 1975; Maher 1984; Singer and Fine 1989; Heller and Evans 1995; Maher 1998; Evans and Heller 2001; Hambach et al. 2008; Hambach 2010) or the accumulation of coarse eolian ferrimagnetic minerals (Zan et al. 2012). Since pedogenesis is controlled by climate, tectonism, dust input as well as geomorphic position, variations in the intensity of laboratory-induced remanent magnetization and magnetic susceptibility, which result from this process, can be linked to orbitally-tuned records of climatic change from marine archives (Heller and Liu 1982, 1984, 1986). However, often there is only a negligible contribution of ultrafine, pedogenicallyproduced magnetic grains to the magnetic susceptibility signal (see e.g. Zan et al. 2012 and references therein). Measurement of magnetic susceptibility of loessic deposits has quickly become an effective tool of correlation between marine and terrestrial records both in international (Thompson and Oldfield 1986; Heller et al. 1987; Kukla et al. 1988) as well as in Hungarian practice (Horváth and Bradák 2004). Anisotropy of magnetic susceptibility within the magnetic minerals of loess sediments provides additional information relating to paleoenvironmental conditions and wind direction (Bradák 2009).

In the present work magnetic susceptibility measurements were implemented on samples deriving from one of the thickest and best-developed last glacial 


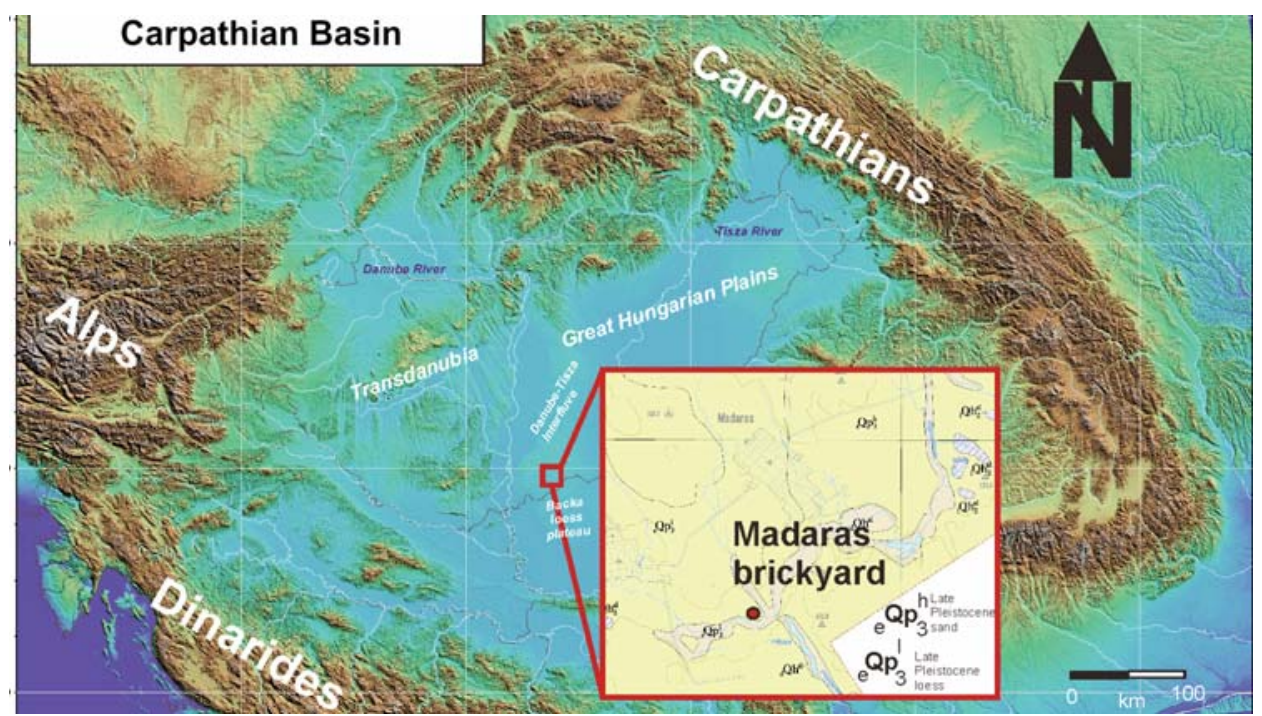

Fig. 1

Geographic location of the studied site

sequences of Central Europe (Bokhorst et al. 2011) found at the northern margin of the Backa loess plateau: the profile of the Madaras brickyard (Fig. 1).

One aim was to compare the findings with the ice core records of northern Greenland in order to establish a high-resolution "decadal" paleoclimatic record for the upper part of the Late Pleistocene, which could contribute to a better understanding of the process of regional landscape and paleoenvironmental evolution documented in other biotic and abiotic proxies so far (Sümegi 2005; Hupuczi and Sümegi 2010). According to available chronological data, the $10 \mathrm{~m}$ thick section developed between 29 and 11 KY cal b2K (Sümegi 2005; Sümegi et al. 2007; Sümegi et al. in prep.). Based on these data an age-depth model was attained for the profile using three different types of fitting methods (Fig. 2).

Of the three scenarios presented, the power and second order polynomial fits yielded equally good results with high R2 values: 0.978 and 0.966 , respectively (Fig. 2a, b). The 3rd order polynomial fit, despite having the best regression coefficient of all fits (0.993), results in a clear turnover of the ages in the middle part of the section between 4 and 8 meters. So for the final work the power fit agedepth model was accepted and adopted. The estimated average sedimentation rate was $0.59 \mathrm{~mm} / \mathrm{y}$. So sampling at 2 -cm intervals, providing a total of 500 samples, yielded us a continuous record with a temporal resolution of ca. 20 years. Ice core proxy records from the NGRIP project are available at the same resolution as well, permitting high-resolution comparison (Rassmussen et al. 2006; Svensson et al. 2006; Andersen et al. 2006). 

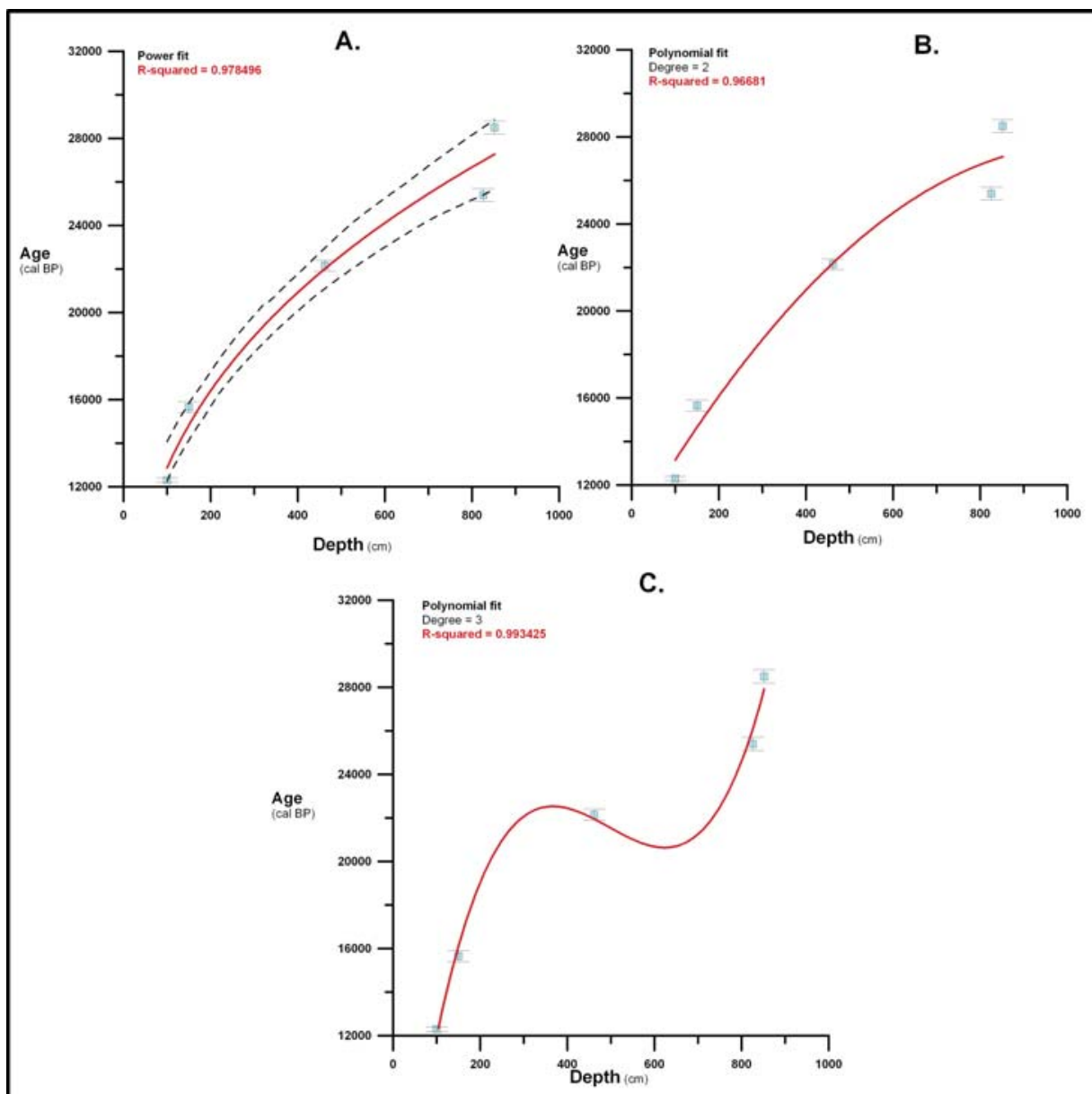

Fig. 2

Age depth models constructed from calibrated $\mathrm{C}^{14}$ data of the studied section (Sümegi 2005; Sümegi et al. 2007, Sümegi et al., in prep.) involving three different fit types (power, 2 nd order and 3rd order polynomial fits)

\section{Geologic setting and site description}

The Madaras brickyard section is located at $46^{\circ} 02^{\prime} 14.39^{\prime \prime} \mathrm{N}$ and $19^{\circ} 17^{\prime} 15.01^{\prime \prime} \mathrm{E}$, at $131.8 \mathrm{~m}$ ASL (Fig. 1). Based on sedimentological parameters, eight sedimentary layers were distinguished within the $10 \mathrm{~m}$-section exposed (Sümegi 2005; Hupuczi and Sümegi 2010) (Fig. 3).

A modified version of the lithological description of the section was adopted from the work of Hupuczi and Sümegi (2010). Local stratigraphic units were 
Climatic fluctuations of the loess section of the Madaras brickyard (Hungary) 333

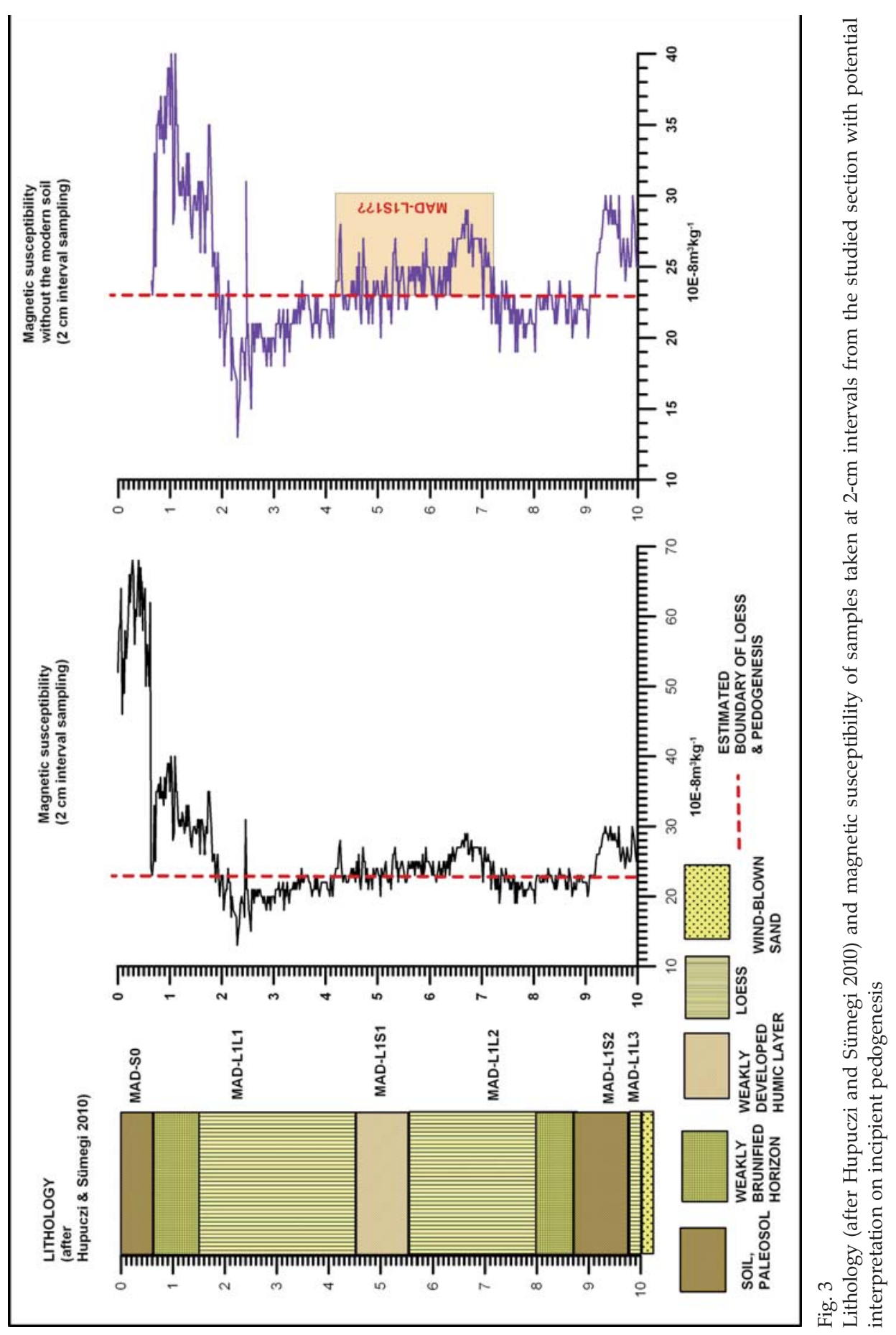

Central European Geology 55, 2012 
assigned a local name (MAD) following Chinese loess stratigraphic nomenclature schemes (Kukla 1987).The bedrock of the section is made up of wind-blown sand overlain by a thin layer of yellowish-brown sandy loess (MAD L1L3). On top of the loess an intensively brunified paleosol layer of pale brown hue (MAD L1S2) developed embedding charcoal fragments of Scots pine and dated to the second phase of the Middle Pleniglacial (Hupuczi and Sümegi 2010). A-D L1S2) developed, embedding charcoal fragments of Scots pine and dated to the second phase of the Middle Pleniglacial (Hupuczi and Sümegi 2010). This paleosol is capped by a weakly brunified horizon between the depths of $8.7-8 \mathrm{~m}$. These deposits are overlain by yellowish-brown, moderately sorted, coarse sandy silt (eolian loess) up to the depth of $5.5 \mathrm{~m}$ (MAD L1L2), corresponding to the terminal part of the Middle Pleniglacial. On top of this loess a weakly brunified soil of light pale brown color developed, embedding carbonate nodules and smaller rhyzoliths (MAD L1S1). This incipient soil is overlain by light yellow sandy loess of Late Pleniglacial age up to the depth of $1.5 \mathrm{~m}$ (MAD L1L1). From the depth of $1.5 \mathrm{~m}$ a weakly brunified zone was identified, grading into the topmost modern soil. The topmost $0.6 \mathrm{~m}$ of the studied section corresponded to the horizon of the modern soil (MAD-SO).

\section{Material and methods}

Environmental magnetic analyses were carried out on bulk samples. Samples were taken at a $2-\mathrm{cm}$ interval from the $10 \mathrm{~m}$-high section, totaling 500 in number. Prior to the beginning of the measurement, all samples were crushed in a glass mortar after weighing. Then samples were cased in plastic boxes and dried in air in an oven at $40^{\circ} \mathrm{C}$ for 24 hours. Afterward magnetic susceptibilities were measured at a frequency of $2 \mathrm{kHz}$, using an MS2 Bartington magnetic susceptibility meter with a MS2E high-resolution sensor. All the samples were measured six times and the average values of magnetic susceptibility were computed and reported as mass-specific susceptibility. Statistical analysis of the results, including descriptive statistics and distribution analysis, was performed using the SPSS 11software. The values were also graphed using Golden Software Grapher 7.0. Finally results were compared with dust accumulation and temperature records of the NGRIP ice core (Rassmussen et al. 2006; Svensson et al. 2006; Andersen et al. 2006) as well as reconstructed mean July paleotemperatures (Hupuczi and Sümegi 2010) via cross-correlation after harmonization to the same temporal scale and resolution of 20 years using the PAST statistical software package (Hammer et al. 2001). Cross-correlation between the recorded MS values and the referred Greenland ice core parameters, as well as the local mean July paleotemperatures was assessed for the entire section and selected temporal windows. The temporal windows chosen embedded the period from the start of the section up to the last glacial maximum (LGM), the entire last glacial maximum (LGM) as defined by Clark et al. (2009), as well as the terminal part of the LGM to the topsoil part of the section (ca. $11 \mathrm{KY}$ b2k). 


\section{Results}

The recorded MS values ranged between 13 and $68^{*} 10 \mathrm{E}-8 \mathrm{~m}^{3} \mathrm{~kg}^{-1}$ in the studied section, with a mean value of 26.52505 (Table 1). The samples seem to show an extremely large variance and highly peaked distribution (Table 1), which can probably be attributed to the very high susceptibility values $(>50)$ of the modern soil compared to the rest of the section (Fig. 3). This is clearly seen in the descriptive statistics of the samples for the entire section and the part without the modern soil. While the mean values are relatively the same, the range is approximately half of that when the entire section is included, not taking into account the observed variances and the other parameters describing the distribution. Without the modern soil the distribution is more flattened, close to that of the normal curve.

Table 1

Descriptive statistics for the recorded magnetic susceptibility values for the entire profile and excluding the horizon of the modern soil (MAD-S0)

\begin{tabular}{|l|c|c|c|c|c|c|c|c|c|}
\hline \multicolumn{10}{|c|}{ Descriptive Statistics } \\
\hline & $\mathrm{N}$ & Range & Minimum & Maximum & Mean & Std. Dev. & Variance & Skewness & Kurtosis \\
\hline MS & 499 & 55 & 13 & 68 & 26.52505 & 9.706169 & 94.20971 & 2.753547 & 7.445057 \\
\hline $\begin{array}{l}\text { MS without } \\
\text { modern soil }\end{array}$ & 468 & 27 & 13 & 40 & 24.18376 & 4.088475 & 16.71562 & 1.175985 & 2.053661 \\
\hline
\end{tabular}

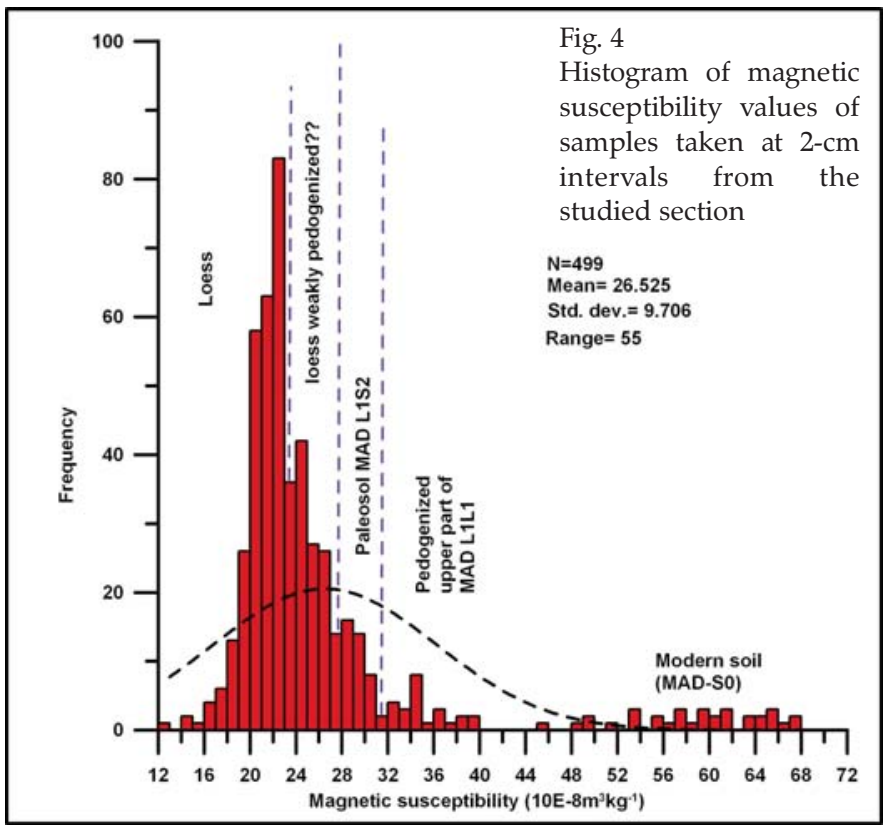

On the frequency histogram (Fig. 4) values corresponding to the modern soil (ca. $52-68^{*} 10 \mathrm{E}-8$ $\mathrm{m}^{3} \mathrm{~kg}^{-1}$ ) are clearly separated from the rest of the samples. Thus, in order to identify smaller fluctuations in the recorded magnetic susceptibility values, during the next step of our analysis the uppermost half meter of the section, corresponding to the level of the modern 
soil, was left out of the evaluation. On the left side of the histogram several peaks appear, which seem to be more or less well separated. Potential boundaries, perhaps corresponding to stratigraphic units, were marked using dashed lines (Fig. 4). The weakly pedogenized zone underlying the modern soil and topping the Late Pleniglacial loess (MAD L1L1) is clearly distinguishable, with values between 32 and $50 * 10 \mathrm{E}-8 \mathrm{~m}^{3} \mathrm{~kg}^{-1}$. The Middle Pleniglacial paleosol horizon can also be clearly separated from the rest of the sequence, with susceptibility values ranging between 27 and $32^{*} 10 \mathrm{E}-8 \mathrm{~m}^{3} \mathrm{~kg}^{-1}$ (Figs 3-4). The remaining left part of the histogram is characterized by a dual peak, again with a potential borderline at the value of ca. $23^{*} 10 \mathrm{E}-8 \mathrm{~m}^{3} \mathrm{~kg}^{-1}$. Values below this limit clearly correspond to the eolian loess deposits of the section. Conversely, susceptibility values between 23 and $27^{*} 10 \mathrm{E}-8 \mathrm{~m}^{3} \mathrm{~kg}^{-1}$ may imply weak pedogenesis of the loess deposits. Based on this observation, a potential boundary between pure dust accumulation not affected by soil formation and weak pedogenesis, was assumed at the $23 * 10 \mathrm{E}-8$ $\mathrm{m}^{3} \mathrm{~kg}^{-1}$ unit, marked by the dashed line in Fig. 3. It is also worth noting here that among the values set aside as characteristic of eolian loess, the most frequent ones are found very close to the proposed boundary of pure dust accumulation and pedogenesis, as shown by the largest peak on the histogram. This implies that during the formation of the entire sequence dust accumulation and soil formation was in a highly fragile equilibrium, mostly confined to the inferred boundary zone. In other words, either the entire sequence is weakly pedogenized, if the magnetic minerals are mainly ultrafine and pedogenic in origin, or, based on the findings of Zan et al. (2012), we should rather assume a relatively constant strong input of coarse eolian ferromagnetic minerals to the site in the major part of the section. This latter option seems more likely, knowing that our visually recorded brunified or weakly pedogenized horizons are all characterized by extremely low MS values compared to the modern soil. This is also clearly seen in the course of susceptibilities, especially on the right graph of Fig. 2, displaying a gradual downward increase of the recorded values from a depth of approximately $2 \mathrm{~m}$ toward the base of the section. Clarification of these assumptions will require further investigations in the future.

Returning to the vertical course of susceptibilities, the major individual stratigraphic horizons identified visually seem to show a good correspondence with the susceptibility values, with one exception. According to our interpretation, based on the susceptibility values observed, the horizon corresponding to the weakly-developed humic layer in the middle of the section (MAD-L1S1) might well be much wider than originally proposed (Fig. 3b). On the other hand, the lowermost Middle Pleniglacial paleosol (MAD-L1S2) and the slightly brunified horizon underlying the modern soil are clearly recorded on the susceptibility curves, although with extremely low values. 

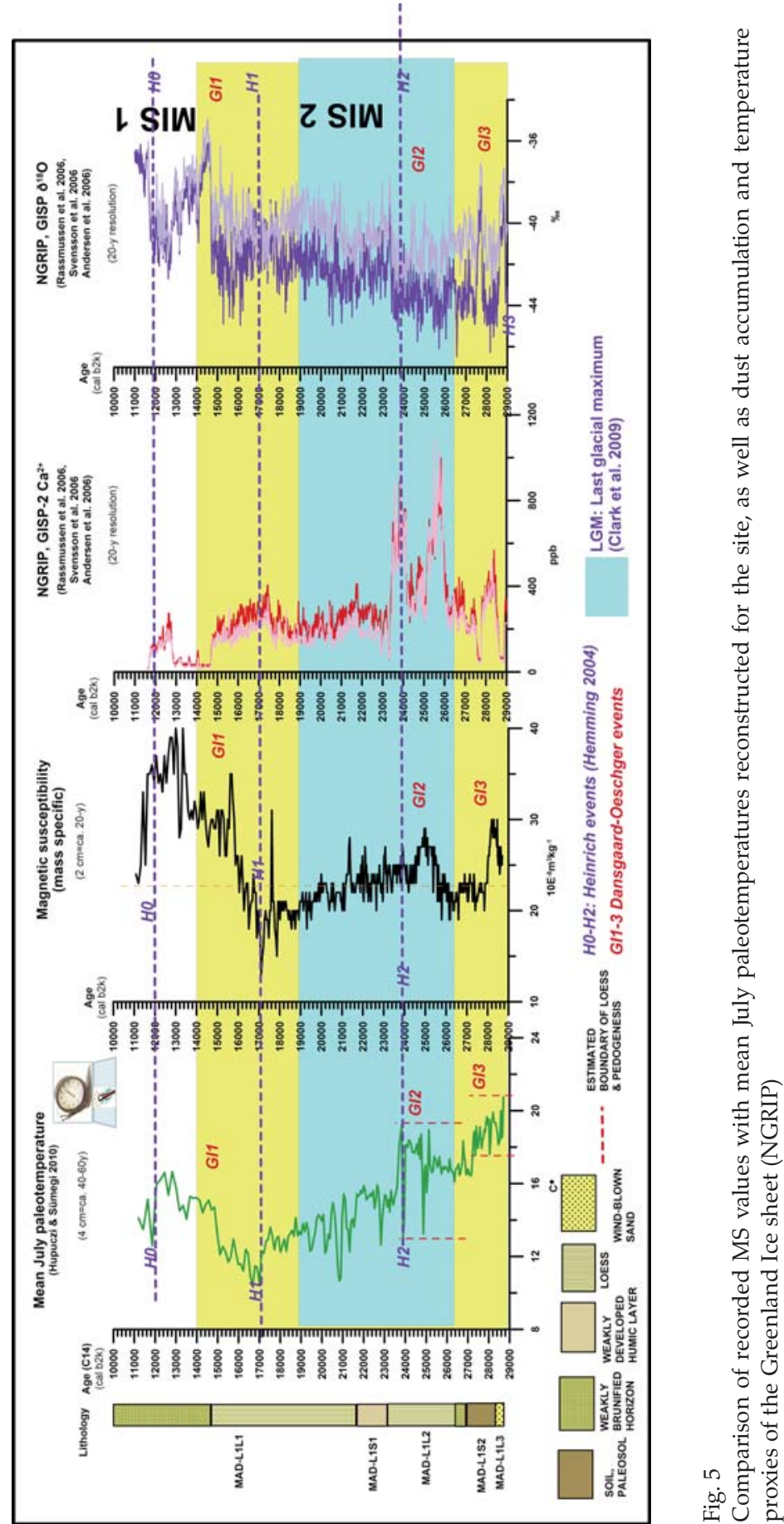

Central European Geology 55, 2012 


\section{Comparison with reconstructed local mean July paleotemperature record and the 20-y NGRIP dust and temperature record}

Variations in magnetic susceptibility values measured in our samples at $2 \mathrm{~cm}$ intervals appear to show a good visual agreement with the 20-y averages of proxy values of paleotemperature $\left(\delta^{18} \mathrm{O}\right)$ and dust influx $\left(\mathrm{Ca}^{2+}\right)$ recorded in Northern Greenland for MIS2 (Rassmussen et al. 2006; Svensson et al. 2006; Andersen et al. 2006) as well as the reconstructed mean July paleotemperatures based on the malacothermometer method (Hupuczi and Sümegi 2010) (Fig. 5). Higher concentrations of Ca ions as well as calculated dust and negative $\delta^{18} \mathrm{O}$ values from the Greenland ice core seem to show a good correspondence with low susceptibility values and low mean July paleotemperatures of our section as a whole (Fig. 5).

In the upper part of the susceptibility profile the stadial of the Younger Dryas ( $\mathrm{H} 0$ at ca. $12 \mathrm{KY}$ ) followed by an interstadial is clearly discernible (Hemming 2004). The first iceberg-calving event (Heinrich event 1 ) dated to around $17 \mathrm{KY}$ (Hemming 2004) is also well-recorded in the sequence, characterized by the lowest susceptibility value as well as the lowest mean July paleotemperature. The last glacial maximum cooling from 26.5 to 19 KY (Clark et al. 2009) is likewise clearly visible in the course of the gradually increasing susceptibility values downsection from $17 \mathrm{KY}$ cal b2k. The second Heinrich event (H2) is recorded but the amplitude is not as high and clear-cut as in the ice core proxies (Rassmussen et al. 2006; Svensson et al. 2006; Andersen et al. 2006) or the mean July paleotemperature record (Hupuczi and Sümegi 2010).

The first three D-O events (Greenland interstadials (GI1-3)) are also clearly recorded in both the MS and the mean July paleotemperature values. In the local paleotemperature record, GI-3 and GI-2 are characterized by the highest temperature values compared to GI-1. The opposite is true for the MS values, where GI-3 and GI-2 are characterized by somewhat higher MS values than the underlying and overlying loess, as well as a weakly developed paleosol horizon overlain by a brunified zone. However, the recorded MS values for GI-3 and GI-2 are much lower than the ones for GI-1. In other words, if we compare records for the Greenland interstadials alone, from 29 to $13 \mathrm{cal}$ b2K there is a general decrease in mean July paleotemperatures accompanied by a gradual increase in MS values. Nevertheless, the trajectory of July paleotemperature evolution, as well as the recorded MS values, seems to be similar during the course of stadials and interstadials.

It is also important to note that for the entire section, the recorded susceptibilities appear to be positively, moderately correlated with the recorded temperature proxy of Greenland (Fig. 6A). In other words MS values seem to be lagging. A moderately negative correlation is observed with the dust influx record of the NGRIP (Fig. 6B), implying a lag in these records compared to our MS values. A weak positive correlation is observable with the local mean July paleotemperature record in line with what was earlier stated for the Greenland 


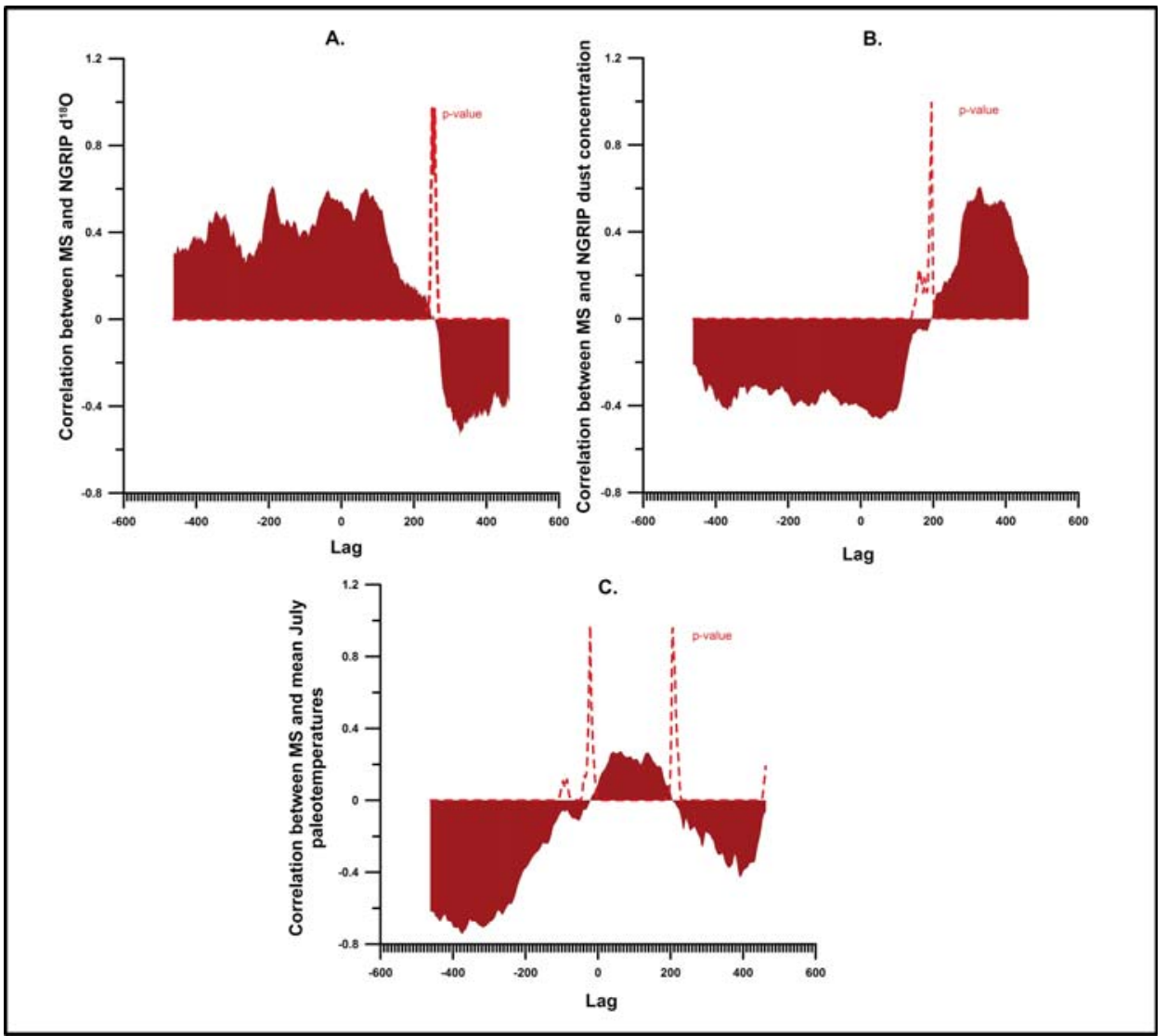

Fig. 6

Cross-correlation between the recorded MS values, temperature (A) as well as dust concentration (B) values of the Greenland Ice sheet (NGRIP) and mean July paleotemperatures reconstructed for the site $(\mathrm{C})$ between 29 and $11 \mathrm{ka} \mathrm{b2k}$

interstadials (Fig. 6C). So MS values seem to be lagging again compared to the local paleotemperature. However, when we compare the records at different time slices or windows, the generally observed pattern might not hold true.

From GI-3 up to the start of the LGM, the recorded MS values seem to show a weak but negative correlation with the recorded temperature proxy of Greenland at the decadal and centennial scale (Fig. 7A). Conversely, correlation with the Greenland dust concentration is weak but positive in this time period (Fig. 7B). Nevertheless, a strong correlation was observed with the local mean July paleotemperatures (Fig. 7C). Thus local climatic factors must have had a more 


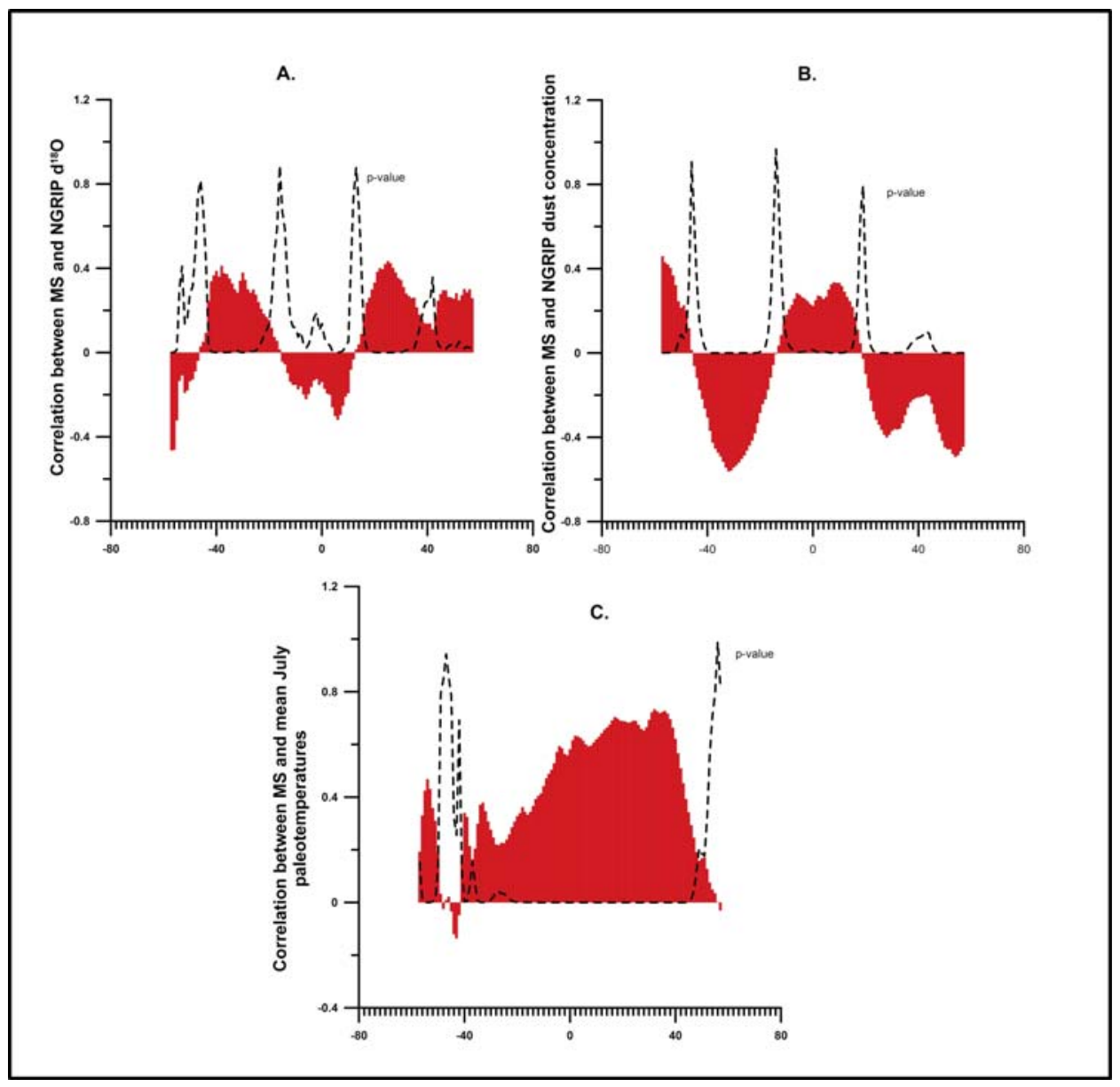

Fig. 7

Cross-correlation between the recorded MS values, temperature (A) as well as dust concentration (B) values of the Greenland Ice sheet (NGRIP) and mean July paleotemperatures reconstructed for the site (C) between 29 and $26.5 \mathrm{ka} \mathrm{b} 2 \mathrm{k}$

prominent effect on loess/paleosol development than the temperature shifts observed over northern Greenland during this period.

During the LGM (Clark et al. 2009) MS values are again moderately negatively correlated with the recorded temperature proxy of Greenland at the decadal and centennial scale (Fig. 8A). Correlation with the Greenland dust concentration is better than in the previous time slice, moderate to good and again positive (Fig. $8 \mathrm{~B})$. Meanwhile a weaker, moderate positive correlation is observed with the local mean July paleotemperatures compared to the previous time slice (Fig. 8C). Here again local climatic factors (although to a somewhat lesser degree than the 


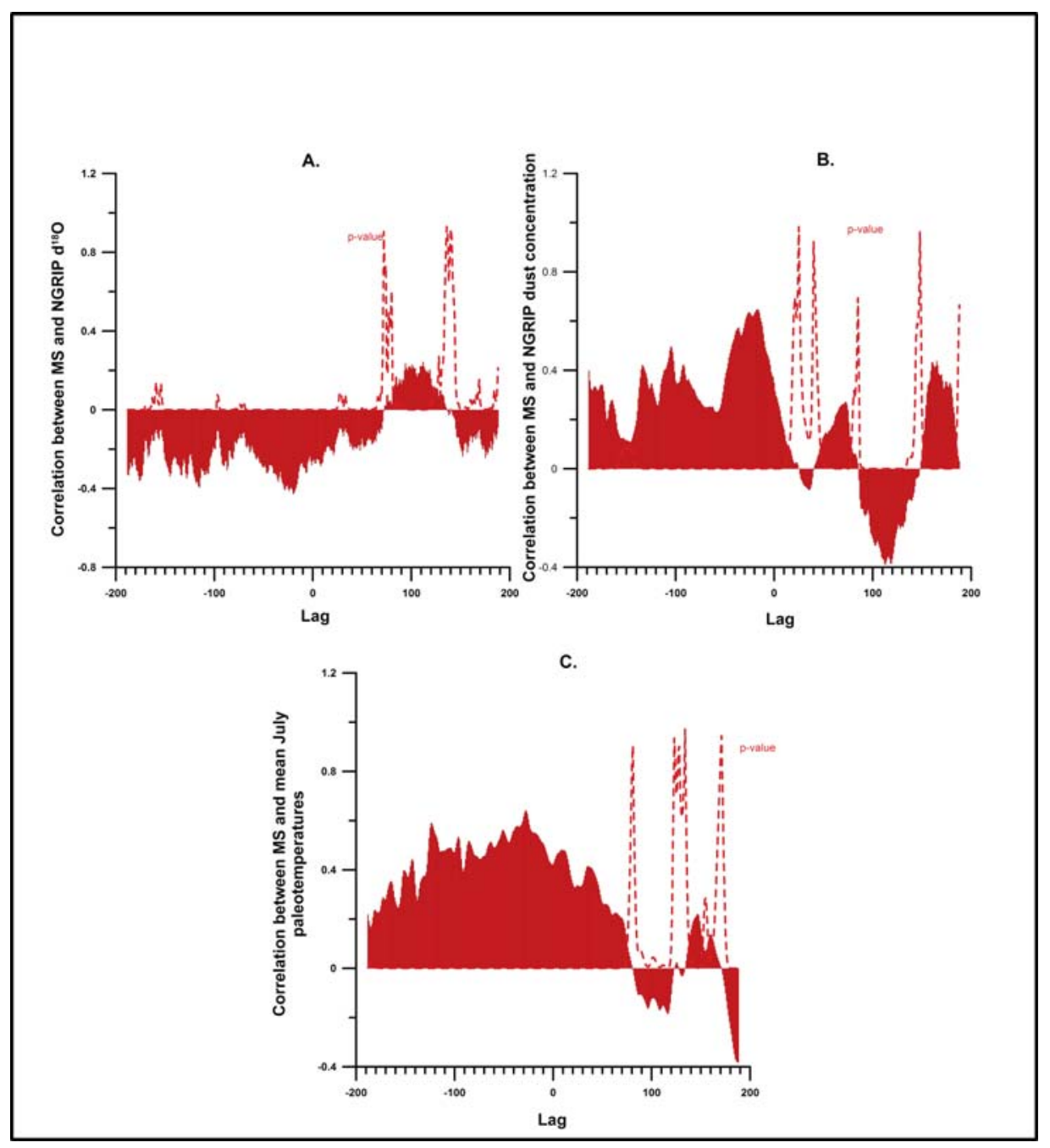

Fig. 8

Cross-correlation between the recorded MS values, temperature (A) as well as dust concentration (B) values of the Greenland Ice sheet (NGRIP) and mean July paleotemperatures reconstructed for the site (C) during the LGM (26.5-19 ka b2K) 


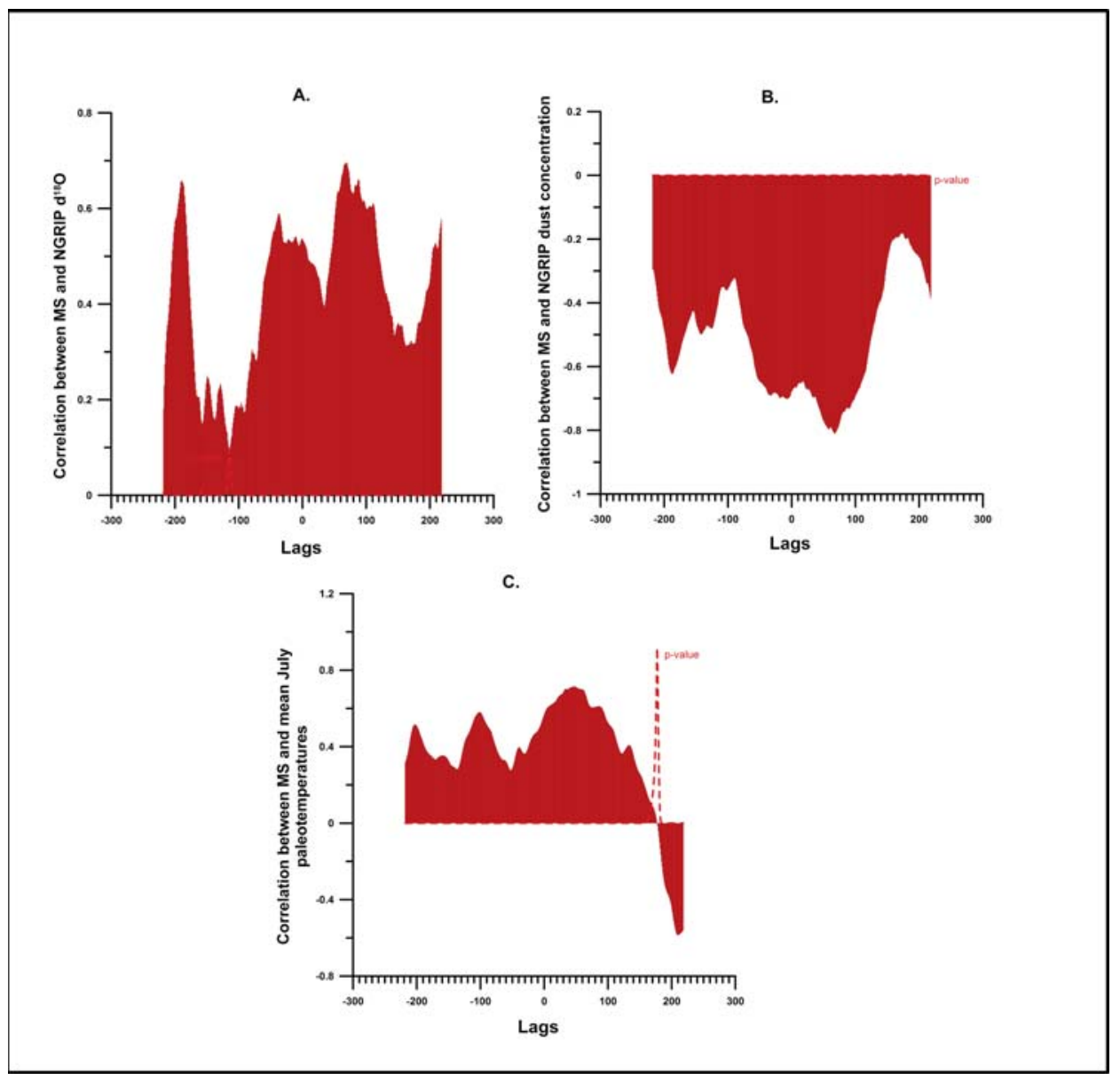

Fig. 9

Cross-correlation between the recorded MS values, temperature (A) as well as dust concentration (B) values of the Greenland Ice sheet (NGRIP) and mean July paleotemperatures reconstructed for the site (C) between 19 and $11 \mathrm{ka} \mathrm{b2k}$

previous period) and dust accumulation must have had a prominent influence on the MS signal and loess/paleosol development compared to temperature shifts over Greenland.

Finally, in the last time slice from the terminal part of the LGM to the Holocene the observed correlation pattern with the Greenland ice core records opposite changes. Here there is a strong positive correlation of the MS values with the temperature proxy for Greenland (Fig. 9A) at the decadal, centennial and millennial scales, accompanied by a strong negative correlation with the dust concentration values (Fig. 9B). Correlation with the local mean July 
paleotemperatures is positive and moderate to strong (Fig. 9C). In this period temperature shifts over Greenland as well as local climatic factors played an equally important role in the development of the MS signal, and thus of the studied loess/paleosol sequence.

\section{Conclusion}

To sum up, our high resolution MS record seems to display a good correspondence with stratigraphic boundaries observed in the field, with one exception. The zone representing the weakly developed humic layer in the middle of the section must be extended in the light of the new findings. The general pattern seems to be congruent with those recorded in other biotic proxies from the site so far. Our results also reveal a strong variability of loess deposition and pedogenesis during the Upper Pleniglacial. According to our findings, dust accumulation and soil formation was in a highly sensitive equilibrium, mostly confined to the border zone during the formation of the entire sequence. Based on the exceptionally low susceptibility values of visually recorded brunified and weakly pedogenized zones, and the dominance of these values in general, we may assume a strong dust input to the site during the LGM. This is clearly seen in the moderate to strong positive correlation of the recorded MS values with the Greenland dust records during the referred time-slice. Millennial time-scale climatic events that characterize the North Atlantic area during the last climatic cycle could also clearly be identified. Among the Heinrich events, $\mathrm{H} 0$ and $\mathrm{H} 1$ are prominently recorded. Meanwhile H2 is present in the MS record but with smaller amplitude than in the local temperature and the ice core records. The three Greenland interstadials (GI-1-3) are also well recorded in the susceptibility values. However, considering these alone there is a gradual decrease of mean July paleotemperatures from GI-3 to GI-1, while an opposite trend is visible for the MS values. The strong correspondence between the Greenland dust record and our MS record up to ca. $19 \mathrm{KY}$ (during the LGM) at the bi-decadal level implies that magnetic susceptibility values were strongly controlled by dust accumulation and the local climate of the area. From 19 KY, however, temperature shifts over Greenland must have played a more prominent role, as seen in the opposite course of dust influx values at NGRIP and susceptibility values at our site.

\section{Acknowledgements}

The authors would like to express their gratitude to one anonymous reviewer for his or her assistance in improving the manuscript. The second reviewer Gábor Újvári's remarks and useful comments for bringing the MS to its final form are also highly appreciated. Special thanks to students of the USZ DGP for their help during the field work. Funding of grants TÁMOP-4.2.1/B-09/1/KONV-2010-0005 and TÁMOP-4.2.2/B-10/1-2010-0012 is acknowledged. 


\section{References}

Andersen K.K., A. Svensson, S.J. Johnsen, S.O. Rasmussen, M. Bigler, R. Röthlisberger, U. Ruth, M.L. Siggaard-Andersen, J.P. Steffensen, D. Dahl-Jensen, B.M. Vinther, H.B. Clausen 2006: The Greenland Ice Core Chronology 2005, 15-42 ka. Part 1: Constructing the time scale. Quaternary Science Reviews, 25, pp. 3246-3257.

Babanin, V.F, A.D. Voronin, L.O. Karpachevskiy, A.S. Manucharov, A.A. Opalenko, T.N. Pochatkova 1975: Some modes of transformation of Fe compounds in soils. - Soviet Soil Science, 7, pp. 83-88

Bokhorst, M.P., J. Vandenberghe, P. Sümegi, M. Lanczont, N.P. Gerasimenko, Z.N. Matviishina, S.B. Markovic, M. Frechen 2011: Atmospheric circulation patterns in central and eastern Europe during the Weichselian Pleniglacial inferred from loess grain-size records. - Quaternary International, 234, pp. 64-72.

Bradák, B. 2009: Application of anisotropy of magnetic susceptibility (AMS) for the determination of paleo-wind directions and paleo-environment during the accumulation period of Bag Tephra, Hungary. - Quaternary International, 198, pp. 77-84.

Clark, P.U., A.S. Dyke, J.D. Shakun, A.E. Carlson, J. Clark, B. Wohlfarth, J.X. Mitrovica, S.W. Hostetler et al. 2009: The Last Glacial Maximum. - Science, 325 (5941), 710-714.

Evans, M.E., F. Heller 2001: Magnetism of loess/palaeosol sequences: recent developments. - EarthScience Reviews, 54, pp. 129-144.

Hambach, U., R.C.E. Schnepp 2008: Magnetic dating of Quaternary sediments, volcanites and archaeological materials: an overview. - Eiszeitalter und Gegenwart. Quaternary Science Journal, 57, pp. 25-51

Hambach, U. 2010: Palaeoclimatic and stratigraphic implications of high resolution magnetic susceptibility logging of Würmian loess at the Krems-Wachtberg Upper-Palaeolithic site. - In: Neugebauer-Maresch, C., L.R. Owen (Eds): New Aspects of the Central and Eastern European Upper Palaeolithic: Methods, Chronology, Technology and Subsistence. Proceedings of the Prehistoric Commission of the Austrian Academy of Sciences, Vienna, pp. 295-304.

Hammer, O., D.A.T. Harper, P.D. Ryan 2001: PAST: Paleontological statistics software package for education and data analysis. - Palaeontologia Electronica 4(1): 9pp. http://palaeoelectronica.org/2001_1/past/issue1_01.htm.

Heller, F, M.E. Evans 1995: Loess magnetism. - Reviews of Geophysics, 33, pp. 211-240

Heller, FB., T.S. Liu 1982: Magnetostratigraphical dating of loess deposits in China. - Nature, 300, pp. $431-433$.

Heller, FB., T.S. Liu 1984: Magnetism of Chinese loess deposits. - Geophysical Journal of the Royal Astronomical Society, 77, pp. 125-141.

Heller, F.B., T.S. Liu 1986: Palaeoclimatic and sedimentary history from magnetic susceptibility of loess in China. - Geophysical Research Letters, 13, pp. 1169-1172.

Heller, F.B., J. Meile, J. Wang, T.S. Liu 1986: Paleoclimatic and sedimentary history from magnetic susceptibility of loess in China. - Geophysical Research Letters, 13, pp. 1169-1172.

Heller, FB., J. Meile, J. Wang, T.S. Liu 1987: Magnetization and sedimentation history of loess in the Central loess Plateau of China. - In: Liu, T.S. (Ed.): Aspects of loess research. Chinese Oceanic Press, Beijing, pp. 147-163.

Hemming, S.R. 2004: Heinrich events: massive late Pleistocene detritus layers of the North Atlantic and their global imprint. - Reviews of Geophysics, 42, pp. 3, RG1005, doi:10.1029/2003RG000128

Horváth, E., B. Bradák 2004: Néhány magyarországi löszfeltárás mágneses szuszceptibilitás szelvényeinek értelmezése (Interpretation of magnetic susceptibility records of selected Hungarian loess profiles). - A 2. Magyar Földrajzi Konferencia Tudományos Közleményei, Szeged, CD-ROM.

Hupuczi, J., P. Sümegi 2010: The Late Pleistocene paleoenvironment and paleoclimate of the Madaras section (South Hungary), based on preliminary records from mollusks. - Central European Journal of Geoscience, 2, pp. 64-70.

Kukla, J. 1977: Pleistocene land-sea correlations. 1. - Europe. Earth-Science Reviews, 13, pp. 307-374

Kukla, G.J. 1987: Loess stratigraphy in Central China. - Quaternary Science Reviews, 6, pp. 191-219. 
Kukla, G., F. Heller, X. Liu, T. Xu, T. Liu, Z. An 1988: Pleistocene climate in China dated by magnetic susceptibility. - Geology, 16, pp. 811-814.

Maher, B.A. 1984: Origins and transformation of magnetic minerals in soils. - PhD thesis. University of Liverpool.

Maher, B.A. 1998: Magnetic properties of modern soils and Quaternary loessic paleosols: paleoclimatic implications. - Palaeogeography, Palaeoclimatology, Palaeoecology, 137, pp. 25-54.

Oldfield, F, J.A. Dearing, R. Thompson, S.E. Garret-Jones 1978: Some magnetic properties of lake sediments and their possible links with erosion rates. - Polskie Archiwum Hydrobiologii, 25, pp. 321-331.

Pécsi, M. 1990: Loess is not just the accumulation of dust. - Quaternary International, 7-8, pp. 1-21. Rasmussen S.O., K.K. Andersen, A.M. Svensson, J.P. Steffensen, B.M. Vinther, H.B. Clausen, M.L. Siggaard-Andersen, S.J. Johnsen, L.B. Larsen, D. Dahl-Jensen, M. Bigler, R. Röthlisberger, H. Fischer, K. Goto-Azuma, M.E. Hansson, U. Ruth 2006: A new Greenland ice core chronology for the last glacial termination. - Journal of Geophysical Research 111, D06102, 2006, doi:10.1029/2005JD006079

Singer, M.J., P. Fine 1989. Pedogenic factors affecting magnetic susceptibility of Northern California soils. - Journal of the Soil Science Society of America, 53, pp. 1119-1127.

Sümegi, P. 2001: A negyedidőszak földtanának és őskörnyezettanának alapjai (Introduction to Quaternary geology and paleoenvironment). - JATEPress, Szeged

Sümegi, P. 2005: Loess and Upper Paleolit hic environment in Hungary. - Aurea Kiadó, Nagykovácsi. Sümegi, P., M. Molnár, É. Svingor, Zs. Szántó, L. Hum, S. Gulyás 2007: The results of radiocarbon analysis of Upper Weichselian loess sequences from Hungary. - Radiocarbon, 49, pp. 1023-1028

Sümegi, P., S. Gulyás, G. Persaits, D.G. Páll, D. Molnár 2011: The chronostratigraphy of the Basaharc Double Paleosol Complex and the Mende Upper Paleosol Complex as seen from recent paleoecological results from the brickyard of Basaharc, Hungary. - Quaternary International, 240, pp. 181-192.

Svensson A., K.K. Andersen, M. Bigler, H.B. Clausen, D. Dahl-Jensen, S.M. Davies, S.J. Johnsen, R. Muscheler, S.O. Rasmussen, R. Röthlisberger, J.P. Steffensen, B.M. Vinther 2006: The Greenland Ice Core Chronology 2005, 15-42 ka. Part 2: Comparison to other records. - Quaternary Science Reviews, 25, pp. 3258-3267.

Thompson, R., F. Oldfield 1986: Environmental Magnetism. - George Allen and Unwin, London.

Zan, J., X. Fang, J. Nie, X. Teng, S. Yang 2012: Rock magnetism in loess from the middle Tian Shan Implications for paleoenvironmental interpretations of magnetic properties of loess deposits in Central Asia. - Geochemistry, Geophysics, Geosystems, 13. Q10Z50, doi:10.1029/2012GC004251. 